\title{
Value chain optimization : maximize don't minimize
}

Citation for published version (APA):

van de Klundert, J. (2007). Value chain optimization : maximize don't minimize. Maastricht University. https://doi.org/10.26481/spe.20070420jk

Document status and date:

Published: 20/04/2007

DOI:

10.26481/spe.20070420jk

Document Version:

Publisher's PDF, also known as Version of record

\section{Please check the document version of this publication:}

- A submitted manuscript is the version of the article upon submission and before peer-review. There can be important differences between the submitted version and the official published version of record.

People interested in the research are advised to contact the author for the final version of the publication, or visit the DOI to the publisher's website.

- The final author version and the galley proof are versions of the publication after peer review.

- The final published version features the final layout of the paper including the volume, issue and page numbers.

Link to publication

\footnotetext{
General rights rights.

- You may freely distribute the URL identifying the publication in the public portal. please follow below link for the End User Agreement:

www.umlib.nl/taverne-license

Take down policy

If you believe that this document breaches copyright please contact us at:

repository@maastrichtuniversity.nl

providing details and we will investigate your claim.
}

Copyright and moral rights for the publications made accessible in the public portal are retained by the authors and/or other copyright owners and it is a condition of accessing publications that users recognise and abide by the legal requirements associated with these

- Users may download and print one copy of any publication from the public portal for the purpose of private study or research.

- You may not further distribute the material or use it for any profit-making activity or commercial gain

If the publication is distributed under the terms of Article $25 \mathrm{fa}$ of the Dutch Copyright Act, indicated by the "Taverne" license above, 


\title{
Value Chain Optimization
}

\author{
maximize don't minimize
}




\section{Colofoni}

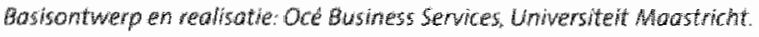

Hhutratie onslog: Cechla Agüro

BSR: $978-90-5681-254-6$

NUR 780

Alle rechten woorbehouden. Miets ut deze witgave mag worden verweehoudigd, opgeslogen in

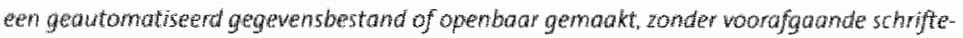
lijke toestemming van de auteur of uitgever. 


\section{Value Chain Optimization \\ maximize don"t minimize}

Prof. dr. Joël Joris van de Klundert Universiteit Maastricht

Aprill 20, 2007

v

M. Universiteit Maastricht 



\section{Introduction: historical perspective}

May 1 start by taking us all back in time around twenty years. and introduce you to a young student of operations research at the Faculty of Economics in Rotterdam? The young student took a course in organization theory, which was taught by a man from the IT industry. who appeared to have little interest in science. He provided the students with more mundane knowledge, such as 'you don't have to wear a suit when you go to a customer, as long as he knows that the sweater you are wearing is extremely expensive. Of course this man didn't make use of classical academic instruments such as written exams. Instead he told the students to individually conduct research projects in real life, in real companies, talking to real people. The research theme he picked ror the young student under consideration was 'logistics'

The young student set out for his task, a little bit nervous, but he knew the task couldn't be avoided by ignoring it. He went to places such as the library of the Dutch 'Eigenladers en Vervoerders Organisatie, EVO, not knowing what an 'Eigenlader' or a 'Vervoerder' was. He learned that logistics dated back from military applications. That Napoleon needed and implemented a strong and advanced organisation to supply his troops with materials and food, while penetrating deeper and deeper into Russia. He learned that logistics was on the rise in the $80^{\prime}$ 's. Not in military applications, but in business settings. In the early years of globalization, when Japanese cars and consumer electronics were penetrating the US and Western Europe.

The young student called up the logistics manager of Ahold, who granted him an entire moming for an interview. And they talked about logistic concepts, about logistic planning, and about planning problems. And even about the plans Ahold had at the time to solve the planning problems using operations research (OR) methods and information technology (IT).

The research project was finished successfully, but more importantly, the young student subconsciously internalized its findings. That the problems and solution methods he studied, which to him had so far been intriguing and beautiful in their own right, can be truly valuable outside the university to business people. This may sound quite obvious to you, but in the late 8 os this was less obvious, to scientists in ivory 
towers and business people in expensive sweaters alike. He leamed that logistics can be viewed as a scientific discipline, but that logistics is also a practical discipline which is core to several of the flagship companies in the Netherlands. And, that quite logically these companies had knowledge, experiences, and challenging unanswered questions, that appeared not to have reached university yet.

While taking his university career in the late 80 's the OR student was not only introduced to logistics but also to the related scientific and practical disciplines of operations management and operations research itself. There are many definitions for logistics, operations. management and operations research, and their number suggests that none of them is perfect. Instead of giving definitions for these disciplines, or the disciplines introduced later in this monologue, I will therefore just. informally introduce them.

The discipline of operations management came to existence early in the $20^{\text {th }}$ century, when scientists like Taylor started studying the fficiency of assembly lines and assembly line workers. Where logistics focuses on moving goods, operations management focuses on creating goods and services. The creation process usually involves a sequence of steps each of which adds value to the product or service, until it is ready to be sold to a customer. The final value that the customer is willing to pay for it is therefore obviously called the customer value. As manu-facturing remained the driving force behind economic growth through the larger part of the $20^{\text {th }}$ century, operations management matured in manufacturing contexts such as automotive, chemicals, consumer goods, et cetera. I will address the topic of service operations management in subsequent sections.

Operations research is not the academic twin of operations management. Operations management and operations research are both mature disciplines with practical and theoretical sides. Like Operations management, operations research studies problems arising in operations. Initially it primarily addressed problems in which the task is to make optimal use of scarce resources. It approaches a problem mathematically, defining it strictly, then modelling it mathematically, and hopefully subsequently solving it. Since solving the models typically requires computer, the rather young discipline of operations research developed steadily since WW II. 
Whatever their exact definitions, operations management and operations research are not restricted to operational problems. That is, they are not restricted to short term planning. Operations are the processes by which a company produces its goods and services. Like any other business function, operations management therefore addresses operational, tactical and strategic problems. Indeed, most of the breakthrough developments are the result of strategic decision making in the domain of Operations Management. Introducing the assembly line to produce cars, as did Henry Ford, serves as a prime example of this statement.

Almost from its conception, OR hasn't been restricted to manufacturing operations. It addressed operations problems in general, and since not all companies are manufacturing companies, not all the attention of operations research goes to manufacturing problems. Especially the operational problems arising in logistical processes have received much attention in operations research. The progress made on solution methods for the Travelling Salesman Problem clearly demonstrates this point. At present, the travelling salesman problem is much more than one of those beautiful mathematical problems. The advanced scientific techniques by which it can be solved, allow a great variety of practical operations planning problems, not only in logistics, but also in manufacturing, and otheir disciplines, to be quickly and effectively solved. 


\section{Supply chain management}

Due to its historical perspective, many of the viewpoints in the introduction appear somewhat old fashioned today. As the sciences of logistics, operations management, and operations research matured. they developed themselves to make valuable contributions, each of them specializing within its own domain. This wert in parallel with real life business trends to plan and control companies tightly per business function. A manufacturing department, a logistics department, a marketing department, et cetera. This organizational model resulted in a functional orientation which naturally caused advances in science to address wersions of these isolated problems. People within the various departments were internally focussed, focussed on their own business process, and not caring much about what happened at the other side of the wall. Hence the resulting focus is also known as a process focus.

Although a process focus is not necessarily bad, it has a tendency to lead to sub optimization. The corporate strategy and goals disappear from the manager's mind, and instead he focuses on local performance indicators, whether they are consistent with the corporate goals or not. In fact in such a setting the various departments can easily perceive each other as enemies: due to the misalignment of performance indicators and objectives, the success of one department may cause nightmares at another. Customers, customer satisfaction, and customer value, which usually are written in capital letters in marketing and sales departments, become less and less visible at other departments who are interested in objectives such as resource utilization, or purchase price. It shouldn't come as a surprise when eventually it turns out that the customer value and satisfaction delivered by the company as a whole is rather disappointing and customers leave.

Operations researchers are vulnerable to such settings because more often than not they don't understand the business implications of their achievements. Let us ill ustrate this point by considering again the Travelling Salesman Problem. The task of a salesman is to sell and therefore a natural objective function for a salesman routing problem would be sales revenwe or sales revenue per customer or per time unit. Instead, in the famous TSP the objective is to minimize the travel time of the salesman which can be interpreted as minimizing logistics cost. 
This type of situation can easily backfire at the operations researcher. Despite the beauty and power of the solution methods, the solutions will be perceived as inadequate. In the post mortem however it is usually too late to address such issues. Operations researchers must therefore understand that if they take up the challenges of improving business processes, they should not find exact methods for suboptimization, but make a visible contribution to corporate objectives.

In retrospect, it is not hard to identify many cases where scientists and business people alike had become quite effective at suboptimization. This was reinforced by the IT systems of the late $80^{\prime}$ s. Since each functional department had its own decentralized authority to make advances in its IT systems, each of them had its own system, suboptimized to its own processes.

But it was not too early to know better than that: Companies like Toyota were already making life very hard for their competitors by taking a different approach. Rather than organizing and planning in terms of functional disciplines and domains, they took a customer focus. They considered the entire flow of goods to the finall customer, back to delivery, warehousing, logistics, manufacturing, purchasing et cetera, and aimed to continuously improve and optimize the primary process as a whole. Avoiding the suboptimizations and workarounds of functional organizations, they became much more effective and efficient, and gained a sustainable competitive advantage.

The obvious question that needs to be addressed when the intention is to optimize the entire process, is the following: What do we optimize? The Total Quality Management philosophy as for instance adopted by most Japanese companies clearly states that the goal is to meet or exceed the customer's expectations. For the moment, I propose to interpret this by stating that the goal is to optimize customer satisfaction. Consequently, it becomes important to understand what determines customer satisfaction, and to understand where in the processes, in the operations, customer satisfaction is created or destroyed. If these relationships are understood, it becomes possible to define a set of consistent performance indicators and objectives for each of the departments which together steer towards optimizing customer satisfaction. 
While continuously improving the processes towards customer satisfaction, companies typically find that improvements in one functional department can be best realized by making changes in another department. If the marketing department finds out that customers want customized delivery times, the logistics department should stop minimizing the travel distance. This alignment of functions within a company coincides with the famous value chain paradigm of Michael Porter as depicted below. During the go's its implementation was in many companies further strengthened by replacing the ald IT systems by an ERP system.
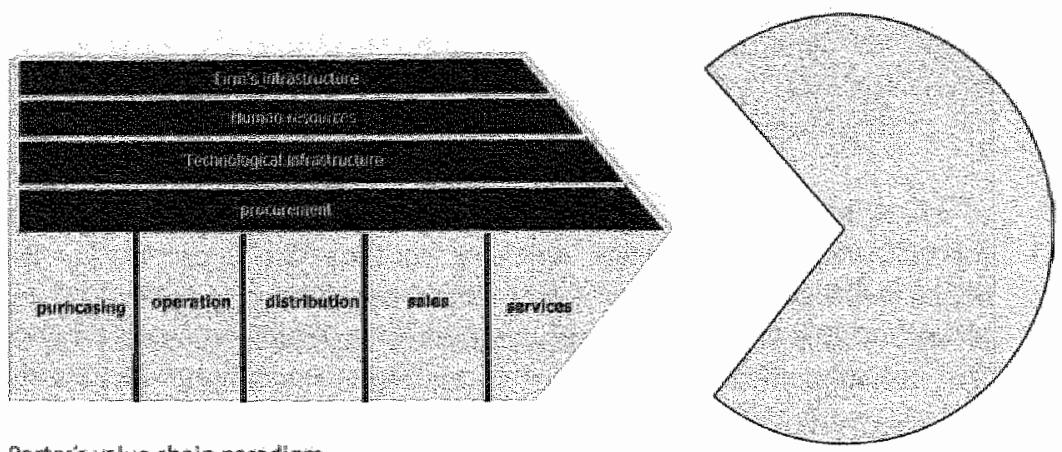

Porter's value chain paradigm

Many of the followers of continuous improvement reached a point where they found out that the most obvious next step to further improvement was not by improving their own operations, but by improving the operations of their supplier, and - as the supplier progressed - at the supplier's supplier. Continuing along this line, a paradigm developed in which the sequence of subsequent primary processes of companies which together produced the products supplied to the customer was viewed as a system. Managing this entire chain is what became known as supply chain management. (See the figure below for a graphical illustration.) Let it be noted that supply chain management not only aims to integrally optimize the different primary processes of the various parts in the chain, but also to align these processes by improving the ways they interact. Obviously, the logistic processes - which are by nature between companies and therefore typically not addressed when processes are optimized in isolation - offered many opportunities for improvement from a supply chain perspective. 

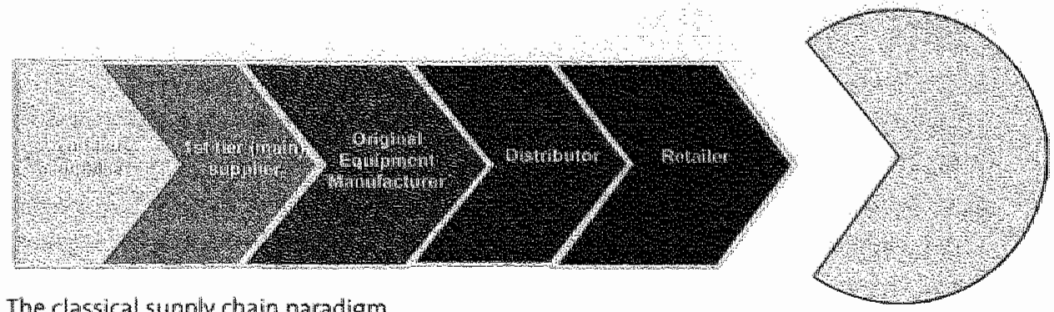

The classical supply chain paradigm

Not withstanding the successes of some companies which have been very effective in bringing true supply chain management principles to practice, the discipline of Supply Chain Management has in my view not lived up to its full potential. In business and academia ike it has often been abused to re-label existing practices. The suboptimization continued but under a new name. More often than not, the activities of the supply chain management department, or demand chain management department, don't regard any process outside of the company borders. In many industries and companies, supply chain collaboration is at its infancy. I will return to this topic later on, and explain why it is so hard to make a true step forward.

Despite these difficulties, there are good reasons to believe that supply chain management is not a discipline that will loose attention quickly. As a result of continued off shoring, out sourcing, and globalization, today's supply chains have become longer. Both in number of parties involved, as in geographical length. Therefore their management is more demanding and requires more attention. At the same time, advances in information and communication technology have made it possible to exchange the information that is required to effectively manage complex global supply chains. And simply because the leading companies are able to leverage these technologles, the pack will have to follow. This point is clearly demonstrated year after year, month after month, in truly competitive global industries such as the automotive and the retail industry. 


\section{Supply Chain Competition}

Somewhere at the end of the $20^{\text {ith }}$ century, our young man made a site visit to the European Distribution Centre of Compaq. This EDC was operated by frans Maas. It was around the time when $C D$ drives were beginning to be avallable on standard personal computers. Hence, Compaq was supplying both machines with and machines without $C D$ drives to the market. Compaq was facing a typical challenge in contemporary supply chain management. It had to run a global supply chain at low cost to offer competitively priced personal computers. This implied for instance cheap production, in Asia, and cheap transport to Europe. 1.e. by boat. As a result the supply chain lead time was in the order of two month. When a product innovation such as the $\mathrm{CD}$ drive enters the market, one typically sees that initially demand for the new product is quite low and prices are very good. At some point however the number brought to the market will increase quite rapidly, and prices will come down. Under such circumstances a supply chain lead time of two month is much too long to respond in such a way that the opportunities are enjoyed and the costs of e.g. obsolete old products are under control. In an industry where product life cycles are short and volumes change correspondingly, a supply chain lead time of two month is not a supply chain management asset but a competitive disadvantage.

Fortunately for Compaq and Frans Maas, there are ways to circumvent the problems sketched above. One solution concept is called Value Added Logistics. The idea is to use the logistic distribution network not only for logistic operations, but also to execute some of the value added steps. By adding this value in a later stage, closer to the market, the ability to respond to changes in demand improves. Value Added Logistics are in fact one of several implementations of the concept of postponement which entails to postpone value adding activities. 
Some of you may already be guessing that what Compaq did, was to ship the PCS without the CD drive, and CD drives with it, so that Frans Maas can perform the value added activity of putting them in depending on market demand. Actually Compag was even deverer. Putting in the CD drives requires some skill and time, whereas the costs. of the CD drives are low, and removing them is easy. Hence, shortly after the initial product introduction stages, Compaq shipped all PCS with CD drive and frans Maas would execute the value adding step of removing. them when appropriate.
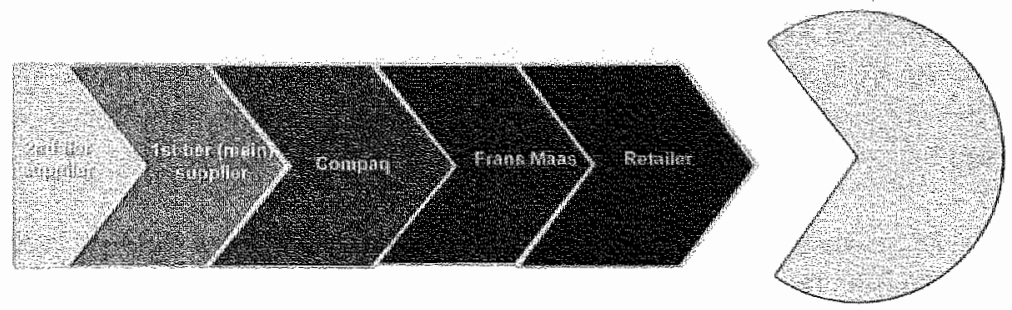

Wha wo stork
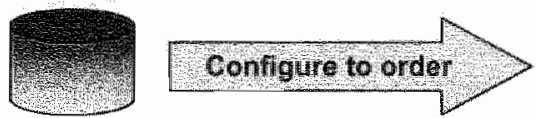

Compagis global supply chain

So how did Compaq fare with this kind of clever tricks? Well Compaq had a really hard time, and they were loosing market share with steady pace. As did the Built-to-Last company Hewlett Packard. in fact the two felt forced to merge, which after some resistance from HP shareholders eventually happened. These undesirable circumstances were not the result of the fact that Compaq was doing a bad job at what they were doing, or that postponement is a bad idea. There was however a competitor doing a much better job, by doing it in an entirely different way. of course, this company was Dell. 
Mike Dell also happened to be a student in the 80 s. He wanted to be in the PC industry, but had difficulty setting up a plant in his student room. Therefore he adopted a different business model. He simply ordered the components and put them together. None of the parts was produced by Dell. Mike Dell extended his concept to assemblePCs tocustomer order. Dell never truly produced machines:giving a customer order it would simply order all necessary components from suppliers and assemble the order computers.

Dell didn't ship PC's by boat. Dell assembled PCs on the continent where they were ordered and made use of very quick transportation modes such as express delivery companies to ensure that $P C s$ that were assembled to customer order would arrive at the customer's home or offices within a couple of days.

For many years, Dell was extremely successful with this concept. Dell Computers became the biggest $P C$ vendor worldwide in 2001. After the numbers two and three, HP and Compaq merged in January 2003 it took Dell around 2 years to be back at the number 1 position again.

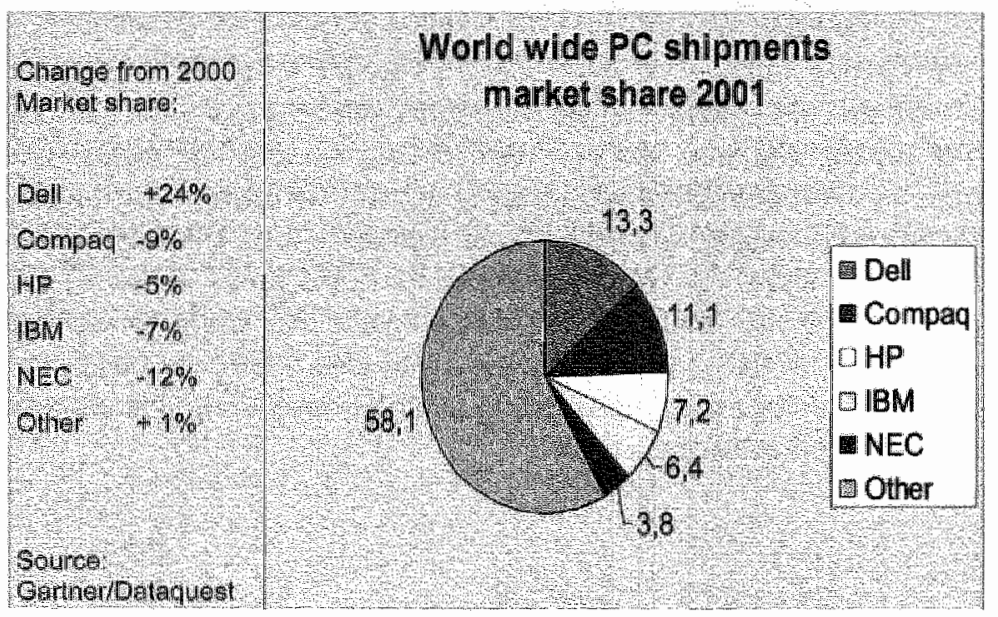


Let us consider Dell's supply chain management concepts in depth. A first difference, which hasn't been mentioned so far, is that Compac would distribute its PC's via standard retail channels, whereas Dell would sell mostly via the internet shop and via call centres. Dell's supply chain involved fewer parties, and therefore less inventory less square meters, less handing, fewer defects, less costs.
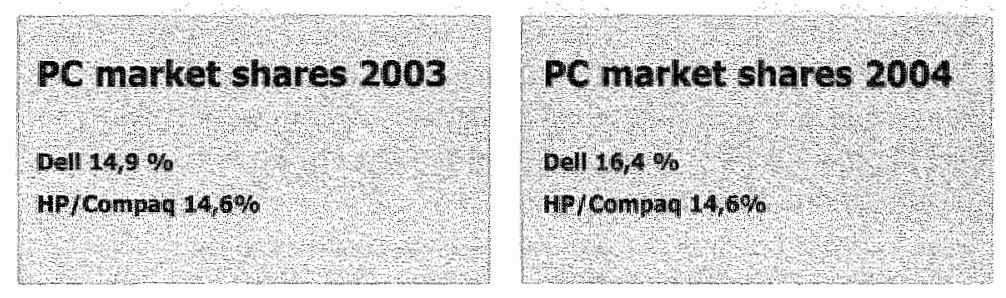

Dell versus HPhCompaq market shares

Moreover, since Dell's supply chain lead time was much shorter, it would be much quicker to market with new or improved components. Without having to sell the old models at reduced prices. Indeed Dell's supply chain enabled Dell to offer better products at lower prices. Dell managed to push the competitive frontier of the industry up, and continued to do so year after year. Dell gained stustainable competitive advantage through supply chain management.
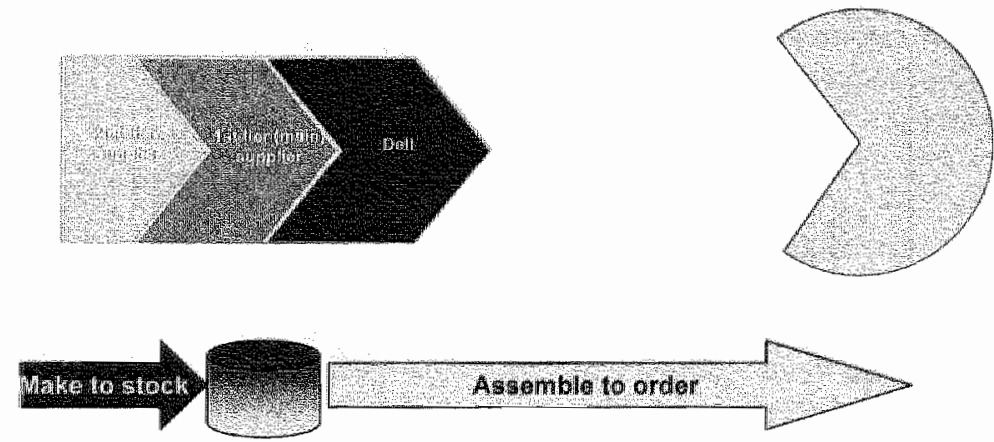

Dell's supply chatr 
We have started to talk about money related concepts such as "Value Added and costs. Dell's success thes partly in its mastery of the flow of goods through the supply chain. Dell's success also lies in its mastery of IT, snce te is far from trivial to assemble, transport and deliver millions of $\mathrm{PC}$, to internet customer order or call centre customer order, within two or three days after order intake. It requires heavy ICT systems, and close collaboration and system integration with the logistics service provider. And on top of that, Dell heavily inwested in scheduling and planning systems, which used advanced operations research techniques, to be able to run its assembly lines effectively. And still, there is more to it. Dell understood very well that doing business is about creating value, and that all other business processes, whether in your own firm or at supply chain partners, are instrumental.

An easy observation is that since that Dell didn't use the retail channel, it avoided the costs and margins of this channel. Moreover. Dell was always quick to market with new products and components, and very responsive to changes in demand. Therefore it avoid the cost of lost sales, of discounting obsolete products, instead it conisistently offered high quality products. Dell also enjoyed an extremely short order-to-delivery cycle. Very quickly after Dell recelved the customer order, it would order the required parts, assemble the PC and ship it. Hence Dell had very low inventories, as can be concluded from the tables below. Notice also how it performs in comparison to other bench mark companies.

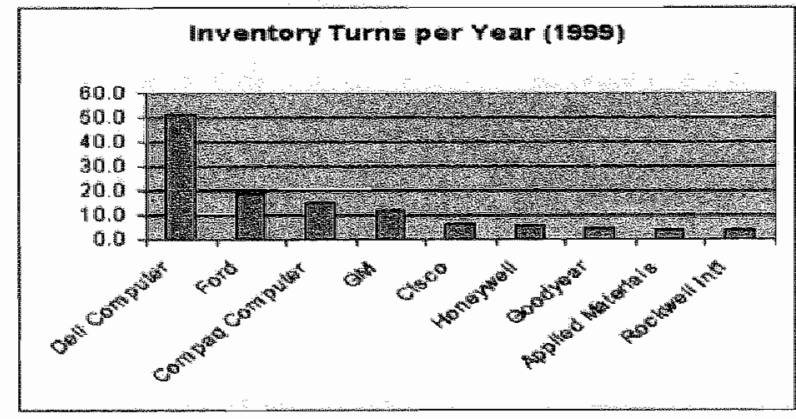

Dells inweratory turns a cross industry bench makk 


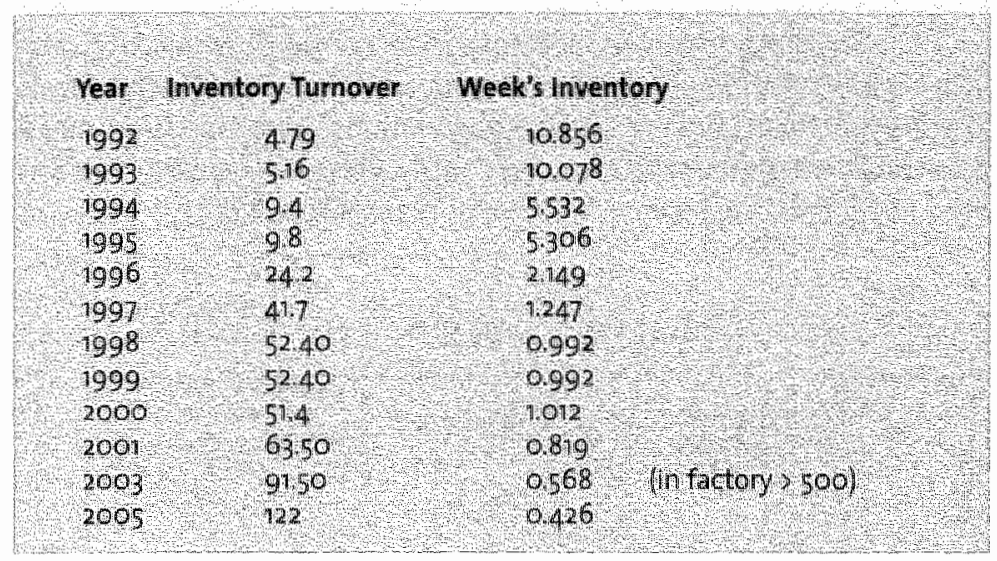

Dell's cortinuous improventient of decreasing inventory

\section{Service delivery}

Before finally moving to value chain management and optimization, it is important to address the importance of services in today's supply chains. In many mature markets, manufacturers have difficulties building a sustainable competitive position on products alone. The goods traded in mature markets are often commodities, and therefore price is an important order winner. To most manufacturers and retailers however, competing on price means low margins, if amy. Moreover, competing on price often induces a transaction based relationship, rather than a long term relationship. This implies low and uncertain future revenues, and hence low sustainability. Hence manufacturers and retailers continuously seek to decommoditize and deepen the customer relationship.

A first possibility to achieve such a long term relationship is by offering after sales services. When for instance Maastricht University buys copying machines, it also needs a service and maintenance contract. Usually this contract is made with the original copier mantacturer, who runs a service organization to this purpose. The copier itself may be a commodity, the service is not, or perhaps not yet. Hence th offers an opportunity to engage in a long term customer relationship which delivers more value to the customer as well as to the copier manufacturer. 
The operational planning problem of dispatching service men to service requests (see figures below) is a prime example of the operations research problems arising in service operations. It appears that due a functional orientation, the esserce of this problem is very poorly understood by service organizations and operations researchers.

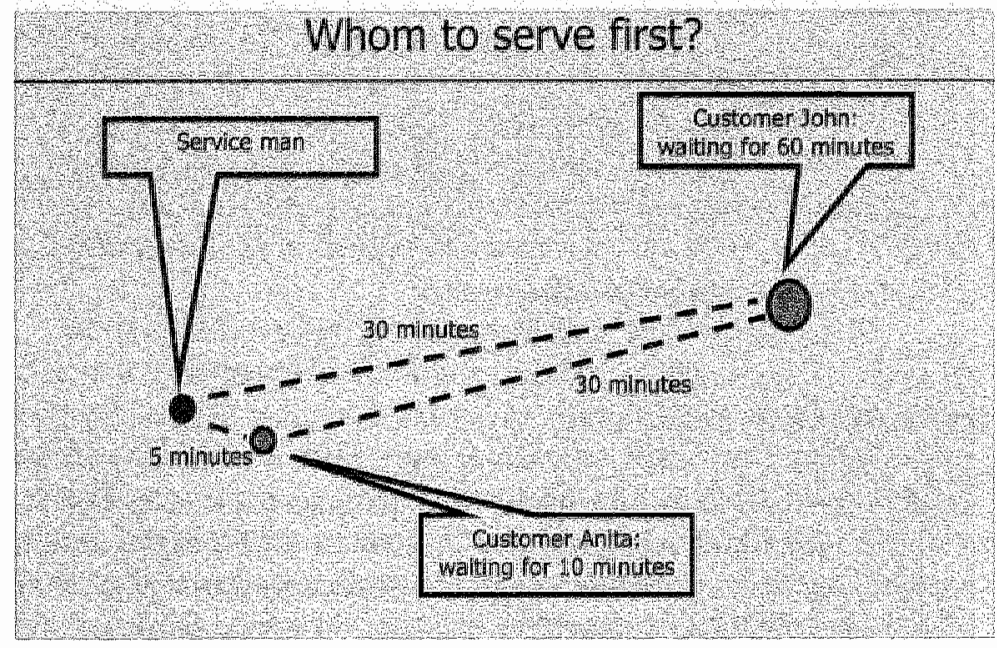

Service man dispatching, serwicing Anita first minimizes average waikng time....

Commonly formulated objectives are to minimize total travel distance, or average waiting time. Bioth of them are internally focussed, process focussed performance indicators which do not even intend to capture customer satisfaction. Therefore, the customer value of maintenance services will automatically improve by scheduling the operations using an objective whicli better captures customer satisfaction. possible cholces are the fraction of requests serviced within an agreed response time threshold, or a function of the waiting time in excess of this threshold. From earlier work with the largest service organization in the Netherlands, ANWB, I have learned that much more appropriate and advanced objectives are possible, but we will not explore in depth here. However, there is much research still to be done on this after salesman problem. and we intend to pursue this direction. 


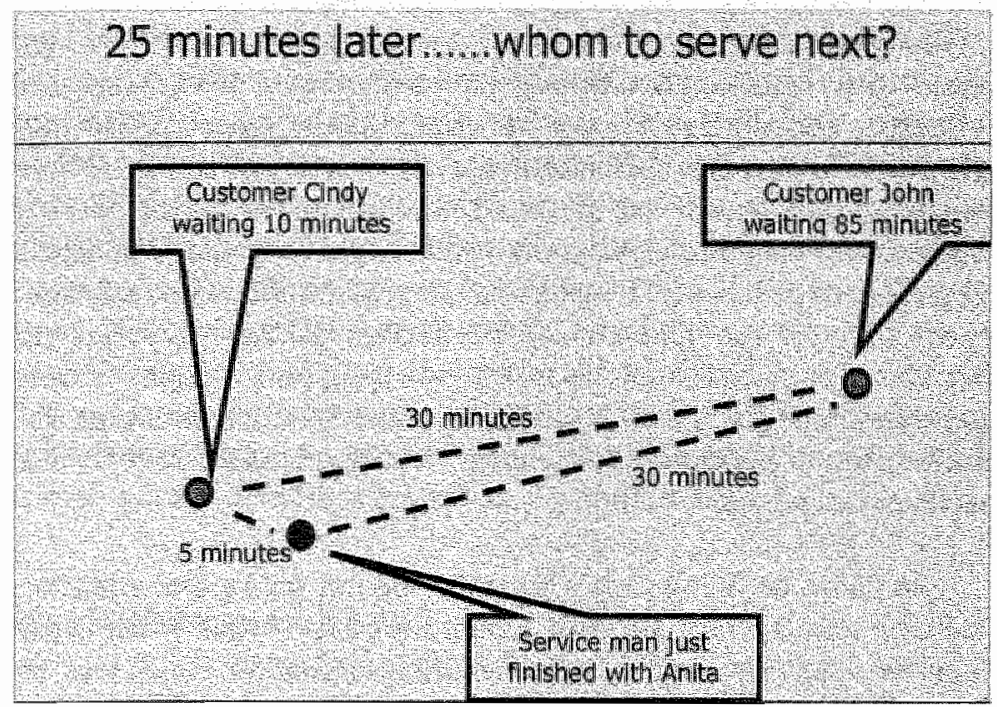

Service man dispatching, servieing Cindy first minimizes average waithong time....

The concept of decommoditizing goods by packaging them with (after sales) services, is sometimes just a step towards a much more service oriented customer relation. For instance, instead of selling copiers one might sell the ability to make copies. The copier itself is then simply a physical requirement to provide the service. In fact, the manufacturer might be entitled to replace it when it chooses to, even if the contract doesn't change. Conversely, if a customer chooses to upgrade its contract - say by doubling the number of pages it can print per minute - it might be the case that the vendor arranges this via internet without a service man even visiting the customer very similar concepts are presently being used in IT services, communication services, e.g. mobile operators, and even in the automotive ind ustry. In such cases service contracts usually ga beyond simply specifying a service response time limit, Instead they include obligations in terms of preventive maintenance and limits on down time per month. Again the operations research literature on the optimization problems arising in the operations planning of such service organizations is still not very customer focused. 
The service and service addition concepts described above make very dear that it would be a misinterpretation of state of the art business models to consider supply chains as sequences of processes delivering physical products. More often than not, the services, or added services for which they provide the necessary physical means are the basis of customer interaction. Although the distinction but also the conjunction of goods and services are quite well understood in operations management literature, the notion of services is often lacking in supply chain literature. Let us accept this as is, but nevertheless also conisider chains which produce goods and/or services and choose a different name for them. We will call them walue chaims. This establishes our first value chain paradigm.

I wouldn't be doing justice to reality by not giving any attention to value chains which are truly service based by nature. While Ford's assembly line was an early manufacturing innovation, which was an early stage in a continuous growth of global manufacturing volumes. the number of people employed in manufacturing, as well as the percentage of GDP of manufacturing industry has steadly gone down over the last decades of the $20^{\text {th }}$ century in western countries. Due to automation fewer people are needed to produce higher wolumes, and/or manufacturing processes are off shored. Instead value is being created in service industries, and that's where people find employment, be it

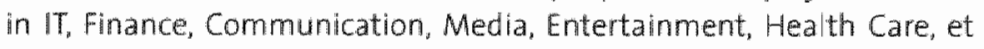
cetera. The concepts of supply chain management can also be applied to value chains in these sectors, but the adoption and implementation of such concepts is often still in its infancy.

As a consultant, as a researcher, as a software vendor and as a customer I have experienced that for instance in health care organizations - let alone health care chains, the current process focus, as opposed to customer focus, is a strong and lough obstacle on the route to creating customer value. I fully agree that our health is extremely precious and that we should therefore be very careful in exposing the health care sector to the laws of market competition and privatization. However, in view of the limits in budgets and the current inefficiency and ineffectiveness, one might just as well conclude that we are paying a high price witli our precious health for the present ineffective state of the industry and the refusal to create an environment where effectiveness and efficiencyare rewarded, as is the case in a competitive enwironment. Above 
we have been considering the issue of service request responsiveness. of course this issue is vital for service organizations which are competing for customers. For ambulances, responsiveness can be a matter of life and death, yet it is a well known fact that in the Netherlands the nationwide responsiveness thresholds can't be and aren't met in reality. Not because of the performance of the people on the ambulance. To a large extent, the shortcomings appear to be in the service chain itself. So do we feel the urgency of the problem? Are we creating an environment in which good performance is rewarded? On the contrary! The worse the performance, the higher the budget increase. In view of the alternative opportunities to spend this money on, the consequence is that value and health is being lost, rather than created.

\section{Value chain management}

The value chain paradigm as introduced above is only half of the value chain story Not every sequence of value added steps truly creates value. If the capital investment needed to create the added value is high and the added value is low, it might well be that the return on investment is rather poor. In such a case the investors might conclude that they are better of putting their money on the bank or in another investment opportunity. They are in the opinion that they have an opportunity cost resulting from insufficient return on investment. Hence creating value is more than simply creating customer value by executing a sequence of walue added steps. It is equally so about creating shareholder value. There is another value chain that should deliver a satisfactory tlow of money from the customer to the shareholder. The link between the two is nicely illustrated by a value driver tree, as depicted in the figure below.
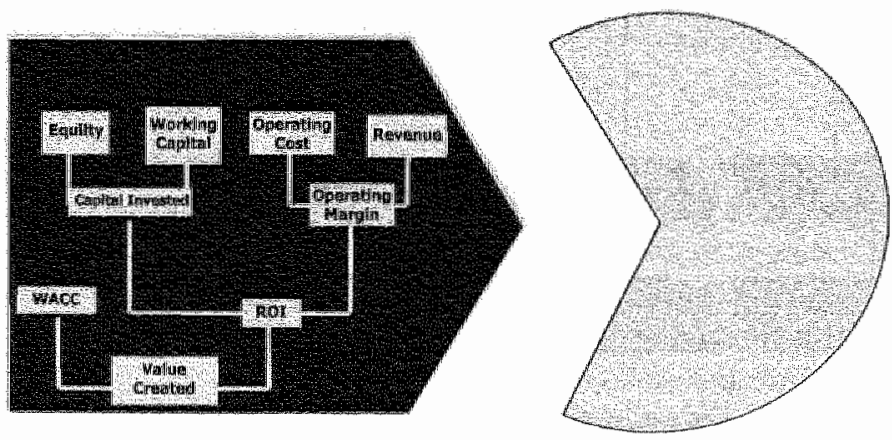

Value driver tree 
In the upper half of the tree, we see the operational costs, and the operationall revenues, and combing the two the operational results. Depending on accounting methods and objectives, the operational result can be translated into a realized return on investment, the money generated by the business processes. In the lower half of the value driver tree we encounter the capital employed, consisting for instance of shareholder capital and loans. Each of the capital providers will have its required return on investment, and taking the sum of them, we obtain the total cost of capital. Value creation for the investors starts when the realized return on investment is greater than or equal to total capital costs. Thus, the other half of the story is the value chain as perceived by the capital prowiders. To complete the analogy, one might say that walue chain management is about meeting or exceeding customer's and shareholder's expectations.

The two value chain dimensions can't be viewed and managed independently from one another. Typically, creating shareholder value without creating customer value cannot be legally done. Conversely, firms which sustainably provide good customer value have good results, and therefore happy capital providers. However, when competition is fierce, customers are more demanding and keeping them satisfied may require to lower prices, and hence to sacrifice business results and thus return on investment.

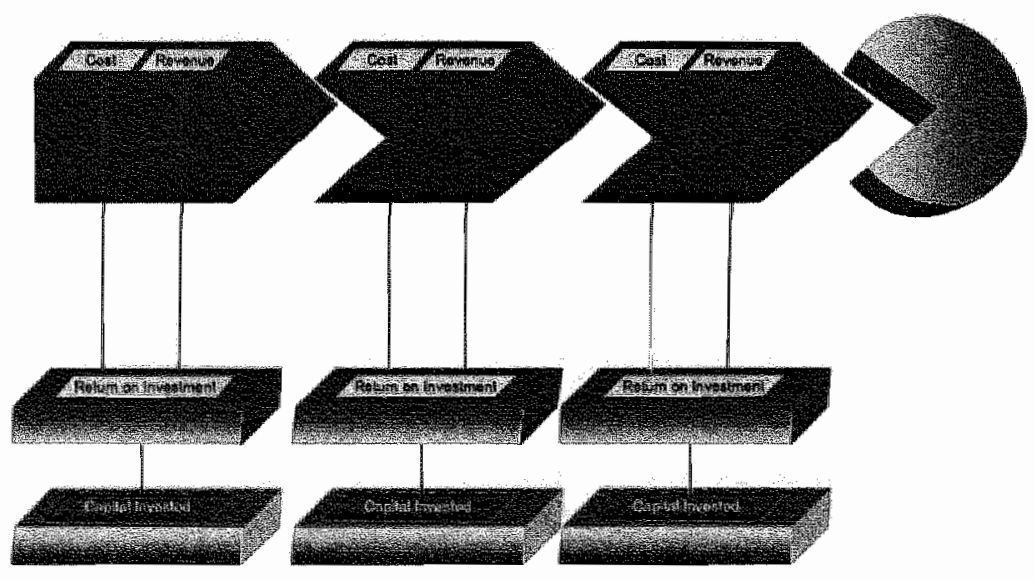

The two dimensions of walue chain management 
Likewise, in a supply chain the total added value must be shared among the firms involved and the shortest route to increasing the return on investment of ane of the parties involved is often to reduce the return on investment of another. The famous exarnple illustrating this case, is the supposed Christmas dinner to which Mr Lopez, chairman of Volkswagen invited his suppliers, and during which he gave to each of them an envelop with a personal message. The message was the reduction in purchase price Volkswagen was going to pay starting from January $1^{\text {st }}$. This inherent conflict of interest explains why many supply chains are struggling with changing the way of managing the chain and hence to reap the benefits of supply chain management. At the functional level, this conflict of interest existed somewhat artificially because of functional organization. At the supply chain level it exists naturally because of differences in shareholders. Added to the fact that value chains are often not simple linear chains, but wather are networks, and that your supplier can also be the supplier of your comm petitor, this causes the obstacles for collaboration and true supply chain efforts to be much too high for most supply chains. This explains why 1 mentioned earlier that supply chain management hasn't realized its full potential yet, and that in practice, it often ends at the company borders. This somewhat disappointing state of affairs cannot be understood well without understanding both dimensions of value chain management and their interrelationship.

Often, the change to true supply chain management is only made in an urgent attempt to copy the practice of a competing supply chain which is doing much better. In such cases it can be considered the lesser of two evils, and it gives a poor and defensive impression. The merger of HP and Compaq, albeit slightly different in nature, can be placed into this category. The supply chain that Dell operated was so competitive that they felt forced to collaborate. And indeed the shareholders played an important role in arranging the merger.

The question then remains how Dell managed to implement such advanced and integrated supply chain innovations as part of an offensive strategy? The assemble to customer order approach that Dell was forced to take, was turned into a powerful customer value machine by Dell, and carefully selecting appropriate supply chain partners, and abandoning others, it grew consistently at enormous growth rates. Since it was the Dell brand that stood for this customer value. it was Dell who 
was calling the shots in this supply chain. Dell used its supply chain power to align the chain and have it run smoothly to its own advantage. Indeed, Dell was powerful enough to improve its own RO at the costs of the Rol of its supply chain partners. Due to its business model Dell was able to work with very low end item and component inventories. and thus with low costs and little working capital. In fact, Dell needed almost none. Every PC that was ordered was paid before Dell ordered its components. Moreover Dell would pay for its components according to the standard payments terms in the ind ustry, say in 30 days. Hence, Dell could put the money on the bank for a month. They enjoyed - and still dol - a negative cash-to cash cycle time. They understand perfectly well that Value Chain Optimization is not only about the value created by the sequence of primary processes, but also about creating shareholder value. Meanwhile many of Dell's suppliers were forced to hold relatively high inventories and hence work with lower margins. Especially so for those supplier's which were supplying commodity components to Dell, and which therefore had little negotiating power, as opposed to Dell which was rapidly gaining market share in a growing market. Notice also that Dell's innovations, such as reducing the cash to cash cycle time are not natural in a supply chain perspective, but perfectly fit the value chain paradigm.

Before turning to the topic of value Chain Optimization, let me ensure you that this monologue is not sponsored by Dell or any of the other companies involved. In fact, it should be mentioned that Dell. which has been admiringly successful for over two decades and whose supply chain management practices are still unmatched, is currently struggling. And it is struggling exactly with the value chain concepts I have stressed above as being disregarded. Dell is exposed to commoditization of its products and therefore with value corrosion due to increased giobal competition, especially from Asia. Although Dell is successful in maintaining growth in volumes, it is struggling with customer value because of bad performance of its service organization, and struggling with shareholder value because of the value corrosion of its products.

Allow me also to make a remark on the importance of creating shareholder value. Everybody is of course allowed to think whatever he or she wants about shareholder value creation. That it will only make the rich icher, or that it offers a mechanism to promote bad human characteristics such as greed. I respect these opinions, and admire people and 
companies who manage to give lower priority to profit and truly favour other values such as the people and planet. But in contrast to privately owned companies, companies whose stocks are traded at the stockmarkets can't ignore the laws of the international capital markets and its players. Especially in these years we see dissatisfied shareholders fighting with management boards over corporate strategy, mergers, takeovers, splitting up companies et cetera. I am not saying it is good or bad, but value chain management has become more important than ever before.

\section{Value chain optimization}

I hope that by now you are convinced as I am that value chain mamagement should be on top of the agendas of today"s business management and research. And hence on the agenda of the ambitious Faculty of Economics and Business Administration of Maastricht University, which positions itself as being international and innovative. But this implies an interest in value chain optimization, which promises to optimize value chain processes. Let us therefore look for a definition of value chain optimization that will live up to this promise. I have searched the literature and - innovative as we are-Google and even the Wikipedia for a definition. It doesn't appear to exist yet. We can be the inventors and innovators. Having taken you all this far, therefore feell owe you a definition, despite my disliking them:

Value chain optimization is the activity of improving walue chain performance by modeling value chain processes, solving the resulting models and underlying optimization problems, and implementing the solutions.

Thus, value chain optimization is not restricted to practice or academia and it shouldn't be. Nevertheless, the contribution that academia can make lies in the modelling and the solution of these models and underlying optimization problems. Obviously this is very much in the spirit of what operations researchers have been doing, or should have been doing so far. Although it remains to be seen what models will emerge, it is likely that it is the context and the questions that will arise which will change, and not the fundamental solution techniques such as combinatorial optimization or queung theory. 
Let me conclude by enlisting several research direction and questions that I think reed to be addressed and will address as we start exploing this new field of research questions:

1. Supply chain optimization standlards. In the classical supply chain context standard modelling templates have been developed such as the supply chain operations reference (SCOR) model, but it hasn been linked yet with a corresponding tool kit of operations research models and solution methods. Since software vendors such as SAP are incorporating the SCOR model into their products, a thorough understanding of corresponding standard tools and their limitations will be of general interest. Even more so since as a successor to the SCOR models a Value Chain Operations Reference (VCOR) model is coming into existence.

2. Vallue adided services. Much work can and should be done in the area of optimizing after sales service operations and the customer value resulting from them. These processes are not yet satisfactorily understood and modelled. Subsequently, these processes need to be addressed jointly with the processes in the supply chains delivering the goods which are originally sold and the spare parts. Serviceability of the products, as well as costs and avallability of the spare parts closely interact with the effectiveness of the service processes, and the interrelationships appear not to have been thoroughly investigated.

3. Alignment of capital cost and value chain structure. Aimost no work appears to have been done to understand the interdependencies between ownership structure, e.g. in terms of shareholders the corresponding cost of capital, and supply chain design and coordination. For example how does the cost of capital of various platyers effect inventory holding costs and subsequently influence optimal stock replemisment policies? Can this lead to additional advantage from techmiques such as VMI, comsignment stocks, or walle added logistics? When should the products change owners? Can such knowledge be used to jointly revise the supply chain ownership structure and design so as to become more effective? What mechanisms or incentives would be required to implement such improvements? 
4. Supply chain risk optimization. The cost of capital is positively correlated with risk. Hence the questions arises how different choices of value chain processes (e.g. single versus dual sourcing), which differ in risk, influence the operational results on the one hand and supply chain risk and thereby it"s cost of capital on the other hand. Since the areas of risk management and supply chain risk management are currently starting to attract considerable attention from executive boards but haven't in the past; one might expect that appropriate models and methods will be seriously considered to be put into practice.

5. Stop minimizing costs. The last research direction is a negative one. Of course reducing costs may lead to higher profits and therefore to higher shareholder value. However, more often than not, reducing costs is getting in the way of value creation. It may be a side effect of a functional orientation and budget cutting while ignoring customer value creation. it maly also result from residing in a commodity industry where in the long term it is unlikely to create a sustainable competitive position that delivers satisfactory shareholder returns. Avoiding such value destruction traps, let us adopt the oversimplifying rule that cost reduction or minimization is for losers. Hence, we stop minimizing tour lengths, minimizing the cost of flows, or the total costs of ownership of purchased goods or services. Instead we look for maximum response routes, for maximum value flows, and for maximum value of ownership. In my farewell address we can spend time on the exceptions to this rule. 


\section{Acknowladgements}

Ladies and gentlemen, here we are April 2007. Ahold is strugging with its shareholders Frans Maas and Compaq don't exist anymore, Dell is having a hard time. Only Google and Wikipedia appear to be in good shape, yet without reference to Value Chain Optimization. Luckly, the young man of the introduction is still around and has the pleasure to be talking to you at this very moment. Before you start putting his lecture to practice, I ask your attention for a couple of people who helped and encouraged me along the way.

The first, and perhaps most important one, is Antoon Kolen. Antoon build the strong and stimulating operations reseanch group at the Department of Quantitative Economics, offered me a Ph.D. position. and my first assistant professorship. Because of his commitment to analyzing combinatorial problems until he fully understood them, and the pleasure which with he used to work on them will, he will always stand as a role model in my academic career. I am proud to be back at what I still think of as his research group.

Yves Crama also certainly deserves mentioning for introducing me into the field of operations research and guiding me on the first steps of my academic career. I have benefited tremendously from working together with him, processing his thoughtful remarks, and his pleasant professional style.

Koos Vrieze has stimulated me to develop myself and follow my professional passions which entall both the theory and practice of operations research. Moreover, he has done me the enormous favour of creating an environment where it could be done I am very grateful for the foint adventure of starting up Mateum and learning what it actually means to successfully put operations research into practice.

Of the many people that I have worked with at Mateum, I mention three with whom I travelled together on my professional paths. I admire their devotion to always achieve first class results, and thank them for being such good company as well. in order of appearance, Ivo van Mulken, Martign Holthuijsen, and Laurens Wormer. 
Finally I thank Stan van Hoesel, whom I have worked with for over a decade by now, and who offered me the opportunity to accept this position, back at the Operations Research group where 1 did my Ph D, and where I gratefully retum. I am confident that we are at the beginning of a valuable cooperation.

Thank you for your attention. 